\title{
CONSIDERING ALLOMETRIC RELATIONSHIPS IN THE ANALYSIS OF SPATIAL TREE PATTERNS
}

\section{A. Pommerening}

Swedish University of Agricultural Sciences SLU, Faculty of Forest Sciences, Department of Forest Ecology and Management, Skogsmarksgränd, SE-901 83, Umeå, Sweden

\section{Z. Zhao}

Research Institute of Forestry, Chinese Academy of Forestry, Key Laboratory of Tree Breeding and Cultivation, State Forestry Administration, Beijing, Box 1958, 100091, China

\section{P. Grabarnik}

Institute of Physico-Chemical and Biological Problems of Soil Science, Russian Academy of Sciences, 2 Institutskaya street, Pushchino, 142290, Russia

\section{АЛЛОМЕТРИЧЕСКИЕ ОТНОШЕНИЯ В АНАЛИЗЕ ПРОСТРАНСТВЕННЫХ РАЗМЕЩЕНИЙ АЕРЕВЬЕВ}

\author{
А. Поммеренинг \\ Шведский университет сельскохозяйственных наук, Швеция, Умео, SE-901 83, Скогсмарксгранд
}

\section{Ж. Жао}

Исследовательский институт лесоводства Китайской академии лесного хозяйства, Китай, 10о091, Пекин, П/Я 1958

\section{П. Я. Грабарник}

Институт физико-химических и биологических проблем почвоведения РАН, Россия, 142290, Пущино, ул. Институтская, 2, корп. 2

Abstract. The study of ecological processes based on the observed spatial tree patterns is an important incentive to research in the area of spatial forest ecology. The difficulties associated with the studies are that it is typically impossible to observe the long-term spatial dynamics of a forest stand and most of the available data relate to spatial patterns representing a single instance in time. To understand the past development of a forest stand, it is useful to examine the correlation structure of tree characteristics with memory properties. The allometric relations between these characteristics are able to preserve a legacy effect even better than the single characteristics. The study addresses the allometric statistical dependence as a multivariate mark in the analysis of marked point patterns. The data included four research plots and two main species in the natural uneven-aged woodland at Lligwy Woods in North Wales (the UK). These plots were compared through the analysis of mark correlation and mark variogram to find evidence of interactions between neighbouring trees. Our findings showed that these interactions were less pronounced for plots with native ash-dominant overstorey than for plots with a non-native sycamore-dominant overstorey. These results contribute to understanding the mechanisms of species alternation at Lligwy Woods and suggest that the two species have adapted to each other and form equilibrium, where the allometric properties play a key role.

Key words: marked point processes, point-pattern analysis, legacy effect, mark correlation function, mark variogram.

For citation: Pommerening A., Zhao Z., Grabarnik P. Considering allometric relationships in the analysis of spatial tree patterns. Russian Journal of Ecosystem Ecology. 2018;3(2). Available from: https://doi.org/10.21685/25000578-2018-2-1

Аннотация. Изучение экологических процессов на основе наблюдаемой структуры пространственного распределения деревьев является важной мотивацией исследований в области пространственной лесной экологии. Трудности, связанные с такими исследованиями, заключаются в том, что, как правило, невозможно наблюдать долгосрочную пространственную динамику древостоя, и большинство имеющихся данных относятся к пространственным структурам, представляющим собой размещение деревьев, отвечающих единственному моменту времени. Аля понимания прошлого развития древостоя полезно проанализировать корреляционную структуру характеристик деревьев, обладающих свойством памяти. Аллометрические отношения между такими характеристиками способны сохранить эффект памяти даже лучше, чем отдельно каждая характеристика. В исследовании рассматривается аллометрическая статистическая зависимость между переменными как многомерная марка в анализе маркированных точечных паттернов. Данные включали четыре временных пробных площадки с двумя основными видами естественного разновозрастного ле- 
са Ллигви в Северном Уэльсе (Великобритания). Эти пробные площади сравнили с помощью анализа маркированной корреляционной функции и маркированной вариограммы, чтобы найти доказательства взаимодействия между соседними деревьями. Наши исследования показали, что для участков, где доминантным видом является клен, эти взаимодействия были менее выраженными, чем для участков с платаном в верхнем ярусе, являющимся для данного местообитания инвазивным видом. Эти результаты вносят важный вклад в понимание механизмов чередования видов в лесах Ллигви и позволяют предположить, что эти два вида адаптировались друг к другу и образуют равновесное состояние, где аллометрические свойства играют ключевую роль.

Ключевые слова: маркированные точечные процессы, анализ точечных структур, эффект памяти, маркированная корреляционная функция, маркированная вариограмма.

\section{Introduction}

In point process statistics, points describe the locations of objects of interest, e.g. plants, and marks provide additional information, thus characterising objects in terms of type, size or shape. The patterns including points and marks are referred to as marked point patterns. The objects described by the points and marks usually interact with each other in a complex way. These interactions much depend on the nature of the objects, e.g. what species of plants they are and on their biology and ecology $[1,2]$.

A common dilemma in spatial forest ecology is that most data available for spatial analysis are socalled snapshot data, i.e. mapped data representing a single instance in time. Point-process methods have rapidly evolved over the last 30-40 years and provided a wide range of possibilities to infer likely processes that have shaped the observed spatial patterns $[1,3,4]$. However, any conclusions drawn from these inferences are associated with a degree of uncertainty, since previous instances of the ecological data under consideration are unknown [5]. Still in many ecological studies it is often necessary to draw conclusions based on snap-shot data.

In such situation one possible strategy to improve information quality is to analyse all available quantitative marks per object. This can be done sequentially, i.e. through a side-by-side analysis of all available marks, but more useful is a simultaneous, multivariate analysis of marked point patterns. Such analyses have been attempted for qualitative marks (e.g. species) and combinations of qualitative and quantitative marks [3, p. 395]. However, we are not aware of attempts to include quantitative marks in a multivariate analysis of marked point patterns.

As a step towards a multivariate analysis of point patterns with quantitative marks, we argue that allometric marks computed from two marks of the same object originally measured in the field may help to describe objects of interest more accurately and to better account for past interaction or so-called legacy effects. Past stand densities and tree species are not present any more, however, they often have had a long-lasting effect on marked point patterns as we are observing them now. Like George Berkeley's "ghosts of departed quantities" allometric relationships are able to preserve some of the legacy effects longer than simple marks. Using points (tree locations) and single marks alone, does not necessarily provide sufficient clues about the processes that have shaped the currently observed pattern.

In this study, we introduced and tested a new approach of considering simple and allometric marks simultaneously for arriving at balanced conclusions concerning marked point patterns and the processes that have shaped them. We applied the approach to point patterns from an Atlantic carboniferous ash community to contribute to the question of species alternation.

\section{Materials and methods}

\section{Data}

The data used stem from a study conducted in 2008 at Lligwy Woods $\left(53^{\circ} 20^{\prime} 57.62^{\prime \prime} \mathrm{N}\right.$, $\left.4^{\circ} 15^{\prime} 39.21^{\prime \prime} \mathrm{W}\right)$ near Moelfre on the Isle of Anglesey in North Wales (the UK). This woodland is the mixed species woodland mainly consisting of native ash (Fraxinus excelsior L.) and non-native sycamore (Acer pseudoplatanus L.). Minor understorey species include hazel (Corylus avellana L.) and holly (Ilex aquifolium L.). Since the 1960s the woods have been privately owned by the Aron family and up to the present day allowed to exist in a natural and unmanaged way and thus represent the typical uneven-aged woodland of Fraxinus communities in North Wales. The parent rock is carboniferous limestone. Four plots of different size were established as part of a master thesis at Bangor University [6]. Plots 1 and 2 (ca. $30 \times 30$ $\mathrm{m}, 0.09 \mathrm{ha}$ ) had an ash-dominant overstorey with a sycamore understorey. Plots 3 and 4 included a sycamore-dominant overstorey with an ash understorey (ca. $40 \times 40 \mathrm{~m}, 0.16 \mathrm{ha}$ ). All four plots were fully mapped (Fig. 1) and in addition stem diameters at breast height $(1.3 \mathrm{~m}$ above soil level, $d$ in 
$\mathrm{cm})$ and total tree heights ( $h$ in $\mathrm{m})$ were measured for all trees with $d>6 \mathrm{~cm}$. The sample plots were deliberately organised in such a way that they capture the process of species alternation in the spirit of a chronosequence, where time is replaced by space [7]. The objectives of the original study were to use point process statistics for investigating the phenomenon of ash and sycamore alternation. This relates to the temporal order of species dominance in the main canopy and the question whether the non-native species may eventually outcompete the native species on the site or whether there is the long-term species equilibrium. Waters and Savill [8] defined alternation as the tendency for canopy tree replacement to proceed in cyclic fashion and

(A)

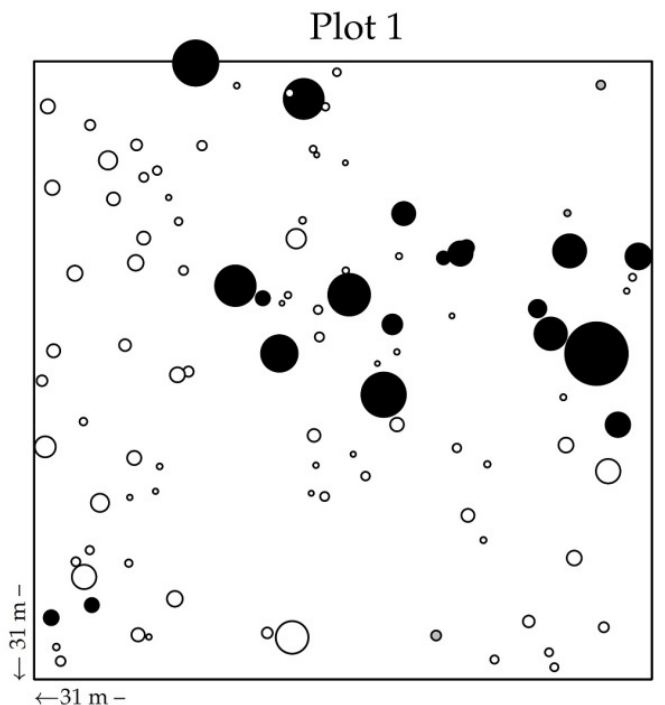

(C)

\section{Plot 3}

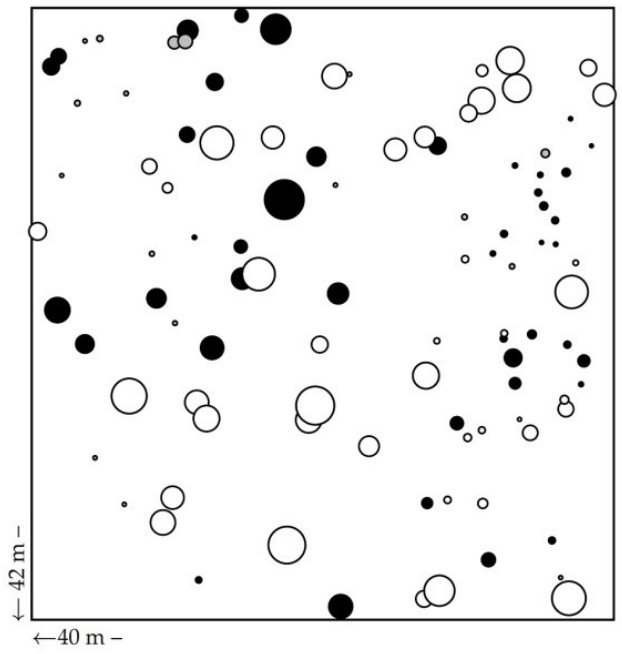

Peterken [9] suggested that alternation is a natural mechanism of maintaining species mixtures. Scurfield [10] and Peterken [11] expressed their concerns that sycamore - a species believed to have been introduced by the Romans - is invading Britain's native ash woods. Although concerns have clearly remained, Peterken [9] suggested that sycamore eventually strikes a balance with ash and other competitors to be part of a mixture and less dominant, even on the most suitable sites. At the time the results of the original study were inconclusive due to the sparsity of species-specific data [6]. In the spatial analysis of this paper, the species marks were therefore ignored and we focused on quantitative marks only.

Plot 2

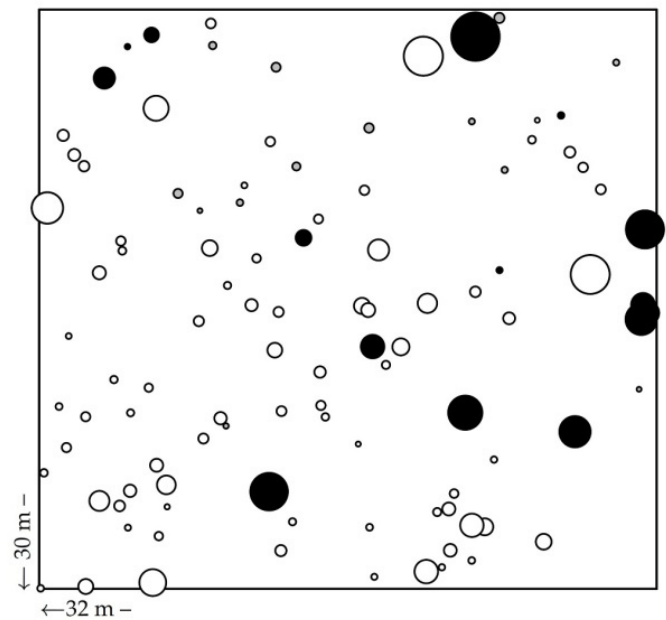

(D)

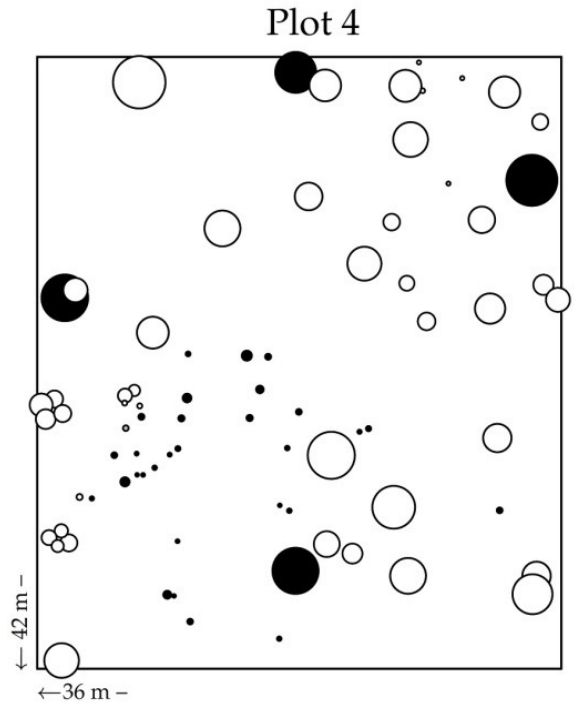

Fig. 1. Maps of the four plots sampled in Lligwy Woods in 2008. The circular symbols are scaled according to tree stem diameters and represent tree locations. (A) plot 1, (B) plot 2, (C) plot 3 and (D) plot 4. Ash (Fraxinus excelsior L.) black, sycamore (Acer pseudoplatanus L.) - white, hazel (Corylus avellana L.) and holly (Ilex aquifolium L.) - grey 


\section{Allometric relationships}

Parts or organs of any organism have characteristic relationships with other parts and organs of the same organism and with the total size of an organism. These are known as allometric relationships and are a result of evolution and functional optimisation for a continued adaptation to changing environmental conditions [12]. Allometric proportions change with age or size as a function of different growth rates at different ages or sizes $[7,13]$. In this study, we consider the heightdiameter ratio, $h / d$, also known as slenderness, i.e. the ratio of tree total height and stem diameter. In general, allometric relationships can be written as

$$
y=b x^{a},
$$

where $x$ and $y$ are two size characteristics of the same organism. $b$ is a constant and $a$ is the allometric coefficient, which is of particular interest, since it is key to the relationship and in plants can be considered as a measure of relative biomass allocation. $a$ is the slope and $\log b$ is the "elevation" (intercept) of the log-log linear relationship of $x$ and $y$ [14]. In our application, $y=h$ and $x=d$, but other allometric relationships are equally interesting, e.g. the so-called crown ratio, where $y=$ crown length and $x=h$. Allometry and the allometric coefficient are related to the concept of relative growth rates. The allometric coefficient is interpretable and can be best calculated by dividing the relative growth rates of $y$ and $x$ [15-17]. If relative growth rates are not available, regression techniques can be applied to $y$ and $x$ as detailed in Niklas and Spatz [14, p. 363].

The $h / d$ ratio is an expression of tree morphology as a result of biotic and abiotic environmental conditions, which first act on the allometric coefficient and cause the specific $h / d$ ratio [18]. The more growing space a tree is granted, the longer its crown and the smaller its height-diameter ratio. For a long time, $h / d$ ratios were used as individualtree stability indicators in silviculture: Large values were considered to indicate low stability and low values suggested stable trees. Open-grown trees typically tend to have an $h / d$ ratio around 45 whilst trees in dense plantations can easily exceed values of 100 . More recently this ratio is seen as an indicator of legacy effects, i.e. it conserves the effects of past stand densities and competition, since a tree is not at liberty to modify this ratio quickly once growing conditions have improved. Often there is almost a linear decline of $h / d$ ratio with increasing stem diameter leading to a negative slope. This can be explained by the fact that height growth tends to decrease more with time than stem-diameter growth due to environmental resistance and hydraulic limitations. On more fertile sites there tend to be larger $h / d$ values than on less fertile sites. As an adaptation to wind, trees tend to maintain a lower $h / d$ ratio on exposed sites [19].

\section{Second-order characteristics}

Second-order characteristics for marked point patterns depend on distance $r$ and quantify correlations between all pairs of points and their marks that approximately occur at $r$. This allows them to relate to specific ecological scales. In this study, we consider two characteristics of mark correlation for quantitative marks [1]. In the past, they have been introduced and discussed as different functions, but they can in fact be considered as one mark correlation function with two different so-called test functions [20]. These test functions, $t\left(m_{1}, m_{2}\right)$, quantify the dissimilarity between marks $m_{1}$ and $m_{2}$ of pairs of trees and are key to the interpretation of the mark correlation function. For the classical mark correlation function $k_{m m}(r)$ [1] the test function used is $t_{1}\left(m_{1}, m_{2}\right)=m_{1} m_{2}$ computing the mark product of pairs of points with intertree distance $r$. The mark variogram $\gamma(r)$ has the test function $t_{2}\left(m_{1}, m_{2}\right)=1 / 2\left(m_{1}-m_{2}\right)^{2}$. For ease of interpretation, the estimation of $k_{m m}(r)$ and $\gamma(r)$ usually includes normalisation terms [1, p. 346]. In the case of the mark correlation function this is the squared mean of the marks, i.e. $\hat{\mu}^{2}$, and the mark variance, $\hat{\sigma}_{\mu}^{2}$, is the normalising factor for the mark variogram. In addition, edge-correction terms and kernel functions apply [1, p. 481 and p. 188]. The estimator of the generic mark correlation function takes the general form

$$
\hat{k}(r)=\frac{1}{c} \sum_{x_{1}, x_{2} \in W}^{\neq} \frac{t\left(m_{1}, m_{2}\right) k_{h}\left(\left\|x_{1}-x_{2}\right\|-r\right)}{2 \pi r A\left(W_{x_{1}} \cap W_{x_{2}}\right)},
$$

where $x_{1}$ and $x_{2}$ are arbitrary points of the point pattern in the observation window $W, k_{h}$ is the Epanechnikov kernel function, $A\left(W_{x_{1}} \cap W_{x_{2}}\right)$ is the area of intersection of $W_{x_{1}}$ and $W_{x_{2}}$ [1, p. 481 and p. 188], relating to the translation edgecorrection [21]. The aforementioned normalisation term is denoted by $c$. In order to focus on the main trends we applied a bandwidth of $2 \mathrm{~m}$.

Both the mark correlation function $k_{m m}(r)$ and the mark variogram $\gamma(r)$ equal to 1 in case of independent marks irrespective of the arrangement of points. Of course, observed functions may differ from 1 even if the independence hypothesis is true. 
In order to assess whether the deviation from 1 is significant, i.e. to check the independence hypothesis, the envelope test is most often used e.g. [1,22]. The test offers graphical interpretations and allows deriving information on scales where ecological processes may operate. Recently, an advanced confirmation analysis by envelope test was suggested $[23,24]$ that took into account the functional properties of spatial statistics. Though the new form of the envelope test, the so-called global envelope test, is statistically rigorous, it suffers from a loss of power because of multiple testing. Thus, in our study we use the less formal pointwise envelope which is also very informative. It is based on 99 simulations of marked point patterns where the locations are fixed while the marks are permuted. The simulated patterns obtained by this procedure correspond to the so-called random labelling hypothesis. Statistical inference is then based on a comparison of observed and simulated functions. If the behaviour of observed functions is not typical of random labelling, we conclude that there may be ecological reasons to expect that the sizes of close trees are related to each other.

All calculations were carried out using the Spatstat package [20] and our own R code [25].

\section{Results}

\section{Basic summary characteristics}

Considering the density measures number of trees per hectare and basal area, the order of plots is reversed as expected: Plot 2 has the largest number of trees and the lowest basal-area value. By contrast, the lowest number of trees is in Plot 4, which shows the largest basal-area value of $58.7 \mathrm{~m}^{2}$. As expected $d_{100}$, the quadratic diameter of the one hundred largest trees per hectare, is closely related to basal area per hectare. The tallest dominant trees can be found in plot 4 (where basal area is highest) and the shortest dominant trees are in plot 2. The $h / d$ ratio of the 100 largest trees per hectare is quite homogeneous throughout all four plots and is consistent with that of dominant trees elsewhere. It is largest in plot 3 and lowest in plot 4. The diameter coefficient of variation indicates that plot 4 has the greatest variation in diameter marks, whilst plot 3 has the lowest. All empirical diameter distributions tend towards a negative exponential shape, plots 3 and 4 are little less than plots 1 and 2 (not shown here). This is supported by the skewness of the empirical diameter distribution.

Table 1

Summary characteristics of the four forest plots in Lligwy Woods. $d_{100}$ is the quadratic mean diameter of the 100 largest trees per hectare. $h_{100}$ is the corresponding height. $d$ coeff. of var. is the diameter coefficient of variation and $d$ skewn.

is the skewness of the empirical diameter distribution

\begin{tabular}{ccccccccc}
\hline Plot & Trees/ha & $\begin{array}{c}\text { Basal area } \\
{\left[\mathrm{m}^{2} / \mathrm{ha}\right]}\end{array}$ & $\begin{array}{c}d_{100} \\
{[\mathrm{~cm}]}\end{array}$ & $\begin{array}{c}h_{100} \\
{[\mathrm{~m}]}\end{array}$ & $h_{100} / d_{100}$ & $\begin{array}{c}d \text { coeff. } \\
\text { of var. }\end{array}$ & $\begin{array}{c}d \text { skewn. } \\
{\left[\mathrm{cm}^{3}\right]}\end{array}$ & $\begin{array}{c}\text { Plot size } \\
{[\text { ha }]}\end{array}$ \\
\hline & & & & & & & & \\
1 & 1051.0 & 39.1 & 53.3 & 22.9 & 43.0 & 0.78 & 2.1 & 0.096 \\
2 & 1083.3 & 35.7 & 47.7 & 22.4 & 47.1 & 0.69 & 1.8 & 0.096 \\
3 & 613.1 & 42.6 & 53.9 & 25.9 & 47.9 & 0.67 & 0.7 & 0.168 \\
4 & 515.9 & 58.7 & 71.3 & 29.8 & 41.8 & 0.82 & 0.8 & 0.151 \\
\hline
\end{tabular}

\section{Allometric relationships}

The scatterplots of total tree height over stem diameter (Fig. 2) show quite different upper asymptotes and curvatures as indicated by the trend lines. As a consequence, the allometric relationships are also quite different. The ash (plots 1 and 2, Fig. 2, A-B) and sycamore dominated (plots 3 and 4, Fig. 2, C-D) overstoreys can clearly be identified. Conversely, the understoreys in plots 1 and 2 have a larger proportion of sycamore and in plots 3 and 4 a larger proportion of ash, respectively. The data clearly support the aforementioned view that height growth falls behind stem growth with increasing tree size. The noisiness of the data can be explained by the uneven-aged and mixedspecies nature of the site where diverse understorey is often present.

From the scatterplots in Fig. 3 we clearly see that the $h / d$ ratio generally decreases with increasing size of the trees (stem diameter $d$ ) as previously stated. Commonly the trend for $h / d-\mathrm{d}$ is roughly linear. By comparing the linear trend lines with the observed data clouds we understand that linearity is stronger in plots 3 and 4 (Fig. 3, C-D) and weaker in plots 1 and 2 (Fig. 3, A-B). Overall noisiness of the data is considerable in all plots and this can again be attributed to the fact that the data were sampled from uneven-aged, mixedspecies woodland. The variance of the $h / d$ ratio 
typically decreases with size. Small trees vary considerably in $h / d$ ratio depending on species and spatial location in the forest stand. The $h / d$ ratios of understorey ash (plots 3 and 4, Fig. 3, C-D)

(A)

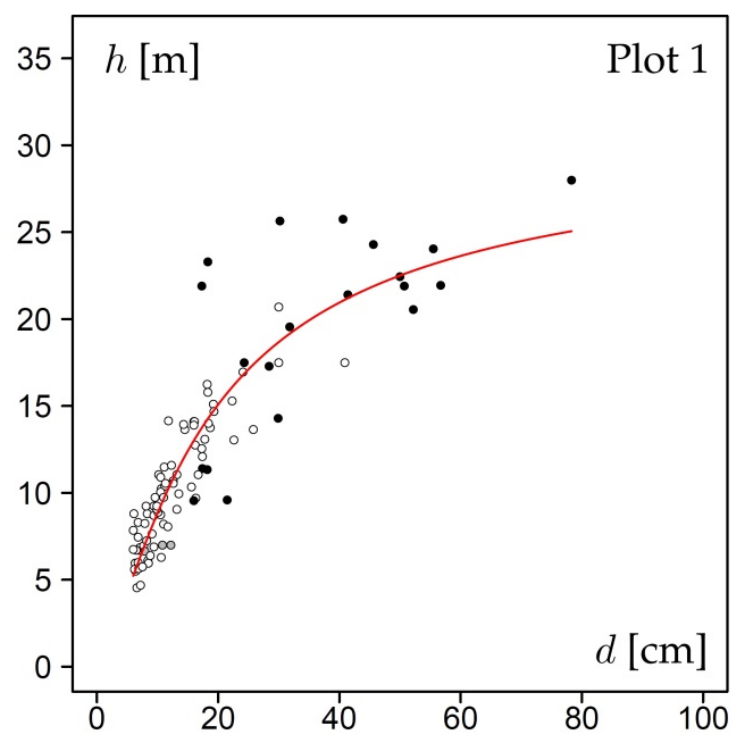

(C)

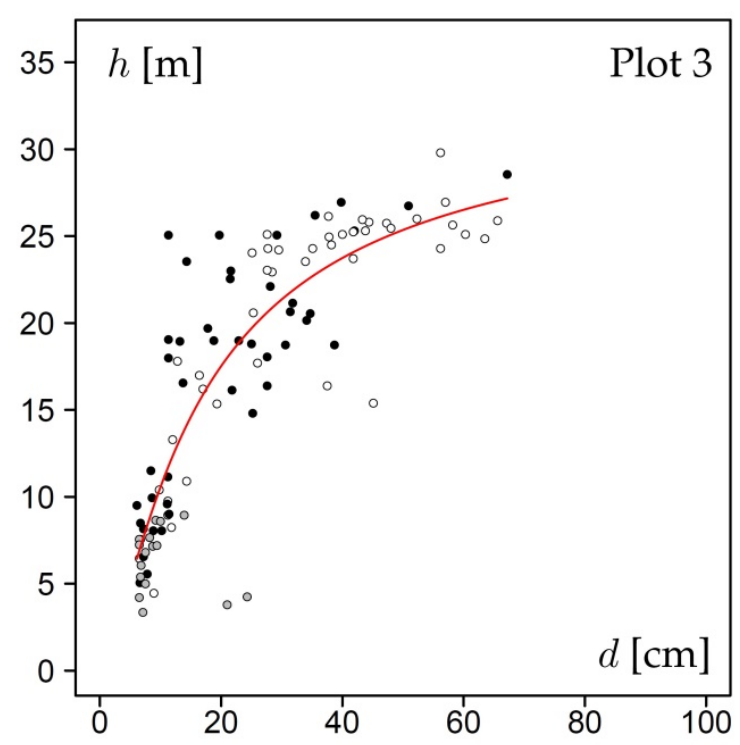

vary more than those of understorey sycamore (plots 1 and 2, Fig. 3, A-B). Understorey ash trees in plots 3 and 4 are also responsible for the largest $h / d$ values.
(B)

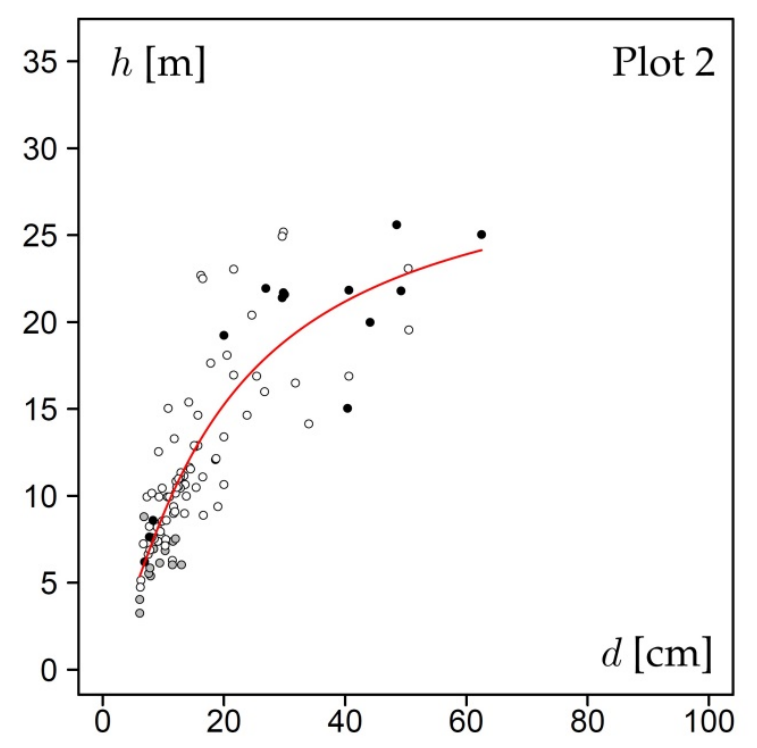

(D)

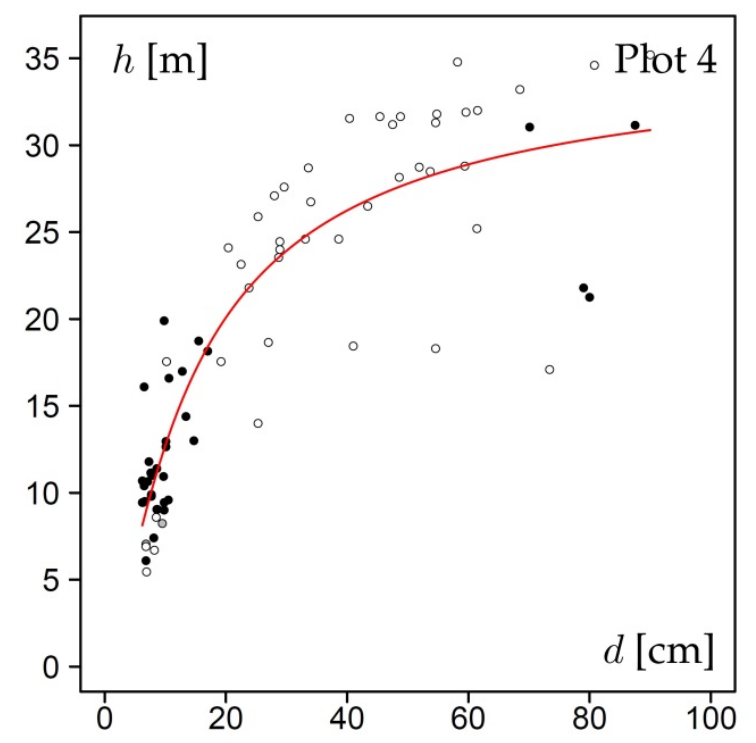

Fig. 2. The two quantitative marks tree stem diameter, $d$, and total tree height, $h$, measured for each tree and their allometric relationship. (A) plot 1, (B) plot 2, (C) plot 3 and (D) plot 4. The trend curves were modelled using the Petterson/Näslund height-diameter model $h=1.3+\left(a_{0} / a_{1}+a_{2} d\right)^{2}[26]$. Ash (Fraxinus excelsior L.) - black, sycamore (Acer pseudoplatanus L.) - white, hazel (Corylus avellana L.) and holly (Ilex aquifolium L.) - grey 
(B)
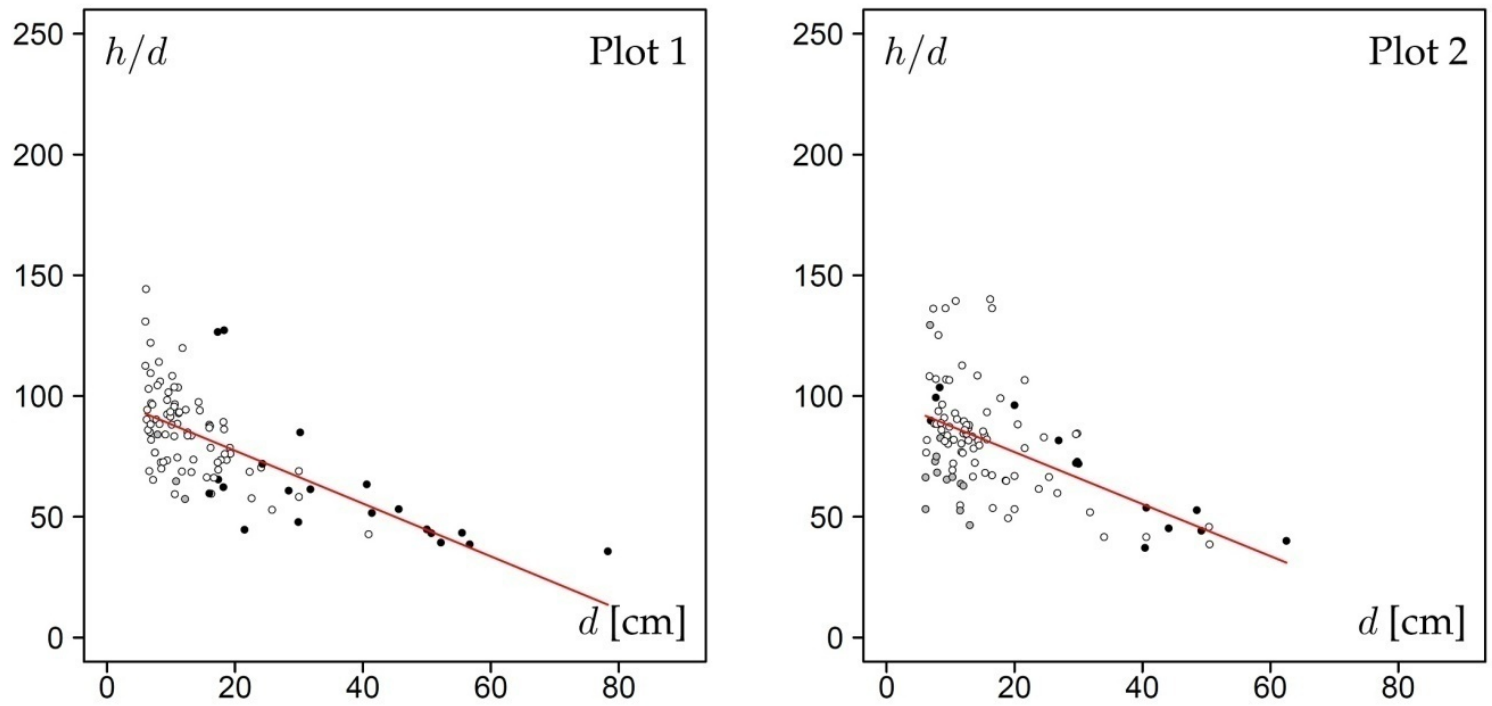

(C)

(D)
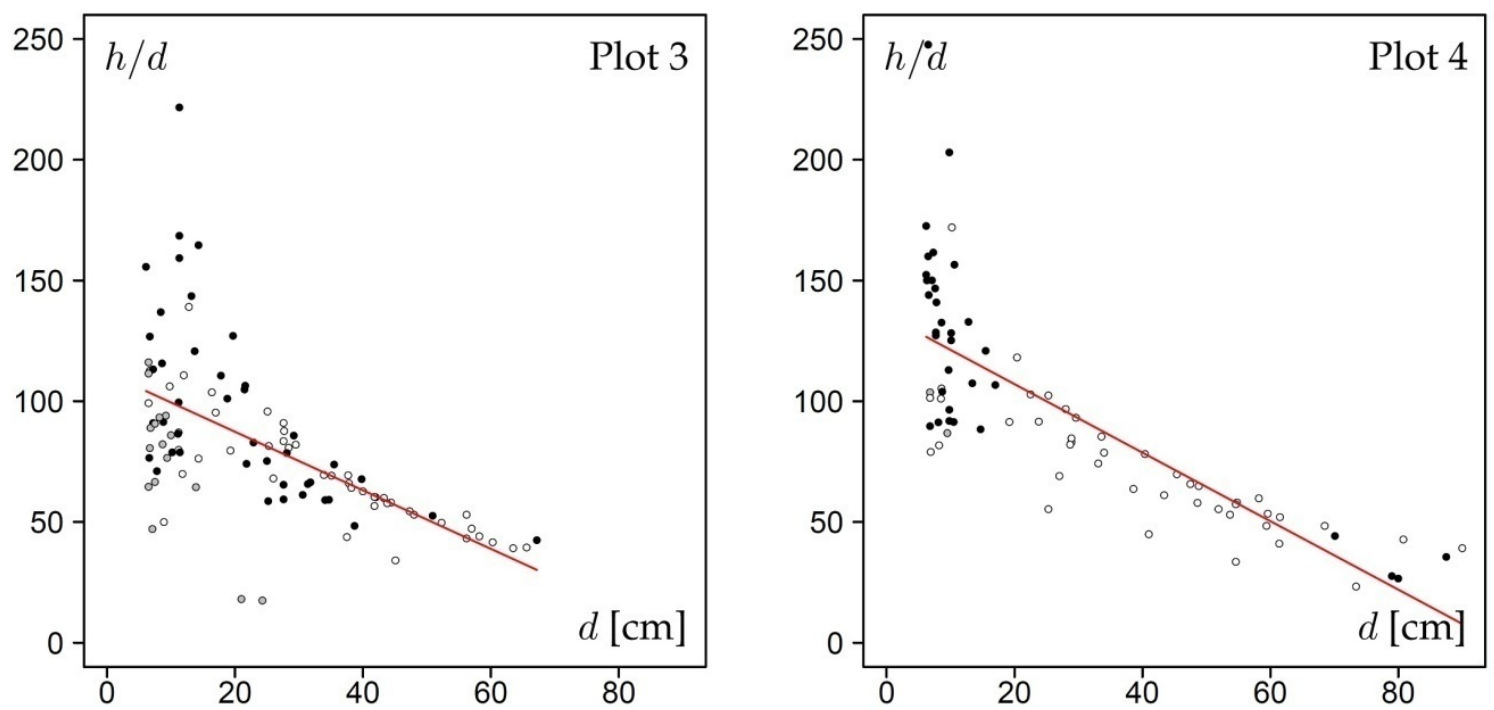

Fig. 3. Scatterplots of the height-diameter ratio, $h$ / $d$ (slenderness), over tree stem diameter, $d$. (A) plot 1, (B) plot 2, (C) plot 3 and (D) plot 4. Ash (Fraxinus excelsior L.) - black, sycamore (Acer pseudoplatanus L.) - white, hazel (Corylus avellana L.) and holly (Ilex aquifolium L.) - grey

\section{Second-order characteristics}

As expected the mark correlation function reveals that in plots 1 and 2, where the overstorey is dominated by ash, total tree heights are nearly completely spatially uncorrelated throughout the range of $r$ (Fig. 4, A-B). Up to $r=2.5 \mathrm{~m}$ there is a curious, slight but significant aggregation of trees with large heights in plot 2 (Fig. 4, B). There were clearer signals in plots 3 and 4 (Fig. 4, C-D), par- ticularly in the latter, suggesting that close neighbours must be either small or one of them must be large and the other - very small. Recall that here the overstorey in these plots is dominated by sycamore.

For stem diameters (Fig. 4, E-H) the trends are similar to those of total height. Again $\hat{k}_{m m}(r)$ suggests that the marked point patterns of plots 1 and 2 largely have independent diameter marks 
throughout the distance range. The effect of pairs of points with marks that are either small or very different in size is stronger here for plots 3 and 4 (Fig. 4, G-H), where parts of the curve are significant.

Turning now to the allometric $h / d$ ratio combining height and diameter marks (Fig. 4, I-L) we can clearly see quite different patterns of $\hat{k}_{m m}(r)$ compared to Fig. 4 (A-H): Particularly in plots 3 and 4 (Fig. 4, K-L) with the sycamore dominated main canopies but also a little in plots 1 and 2 (Fig. 4, I-J), the mark correlation function takes large values at small $r$, which gradually decrease with increasing $r$. This overall trend in conjunction with Fig. 3 indicates the clusters of small trees (small both in terms of total height and stem diameter, as we have understood from Fig. 4, A-H) in the understorey with large $h / d$ ratios. This understorey effect is particularly strong in small ash trees, where the overstorey is dominated by sycamore, but also, where tree density is lowest in terms of number but largest in terms of basal area. We also recall that it is specific for plots 3 and 4 that the linearity of $h / d$ over $d$ is strongest. It is also interesting to note that the mark correlation functions with $h / d$ marks are significant for all plots. The specific $h / d$ ratios of small trees in clusters dominate the shape of the mark correlation function.
(A)

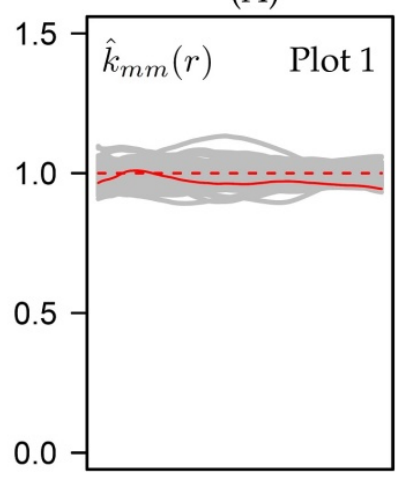

(E)

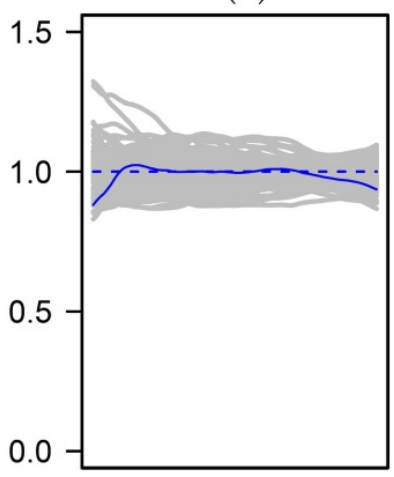

(I)

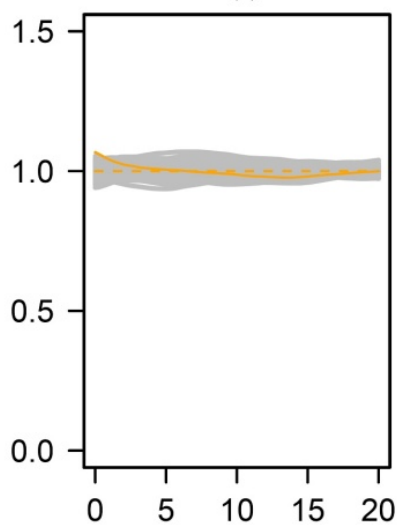

(B)

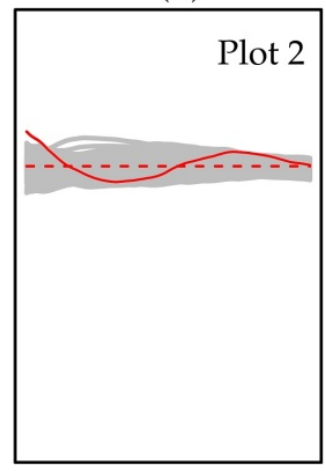

(F)

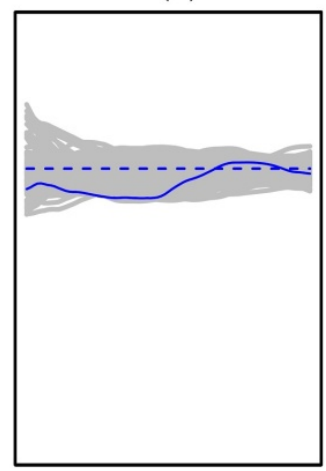

(J)

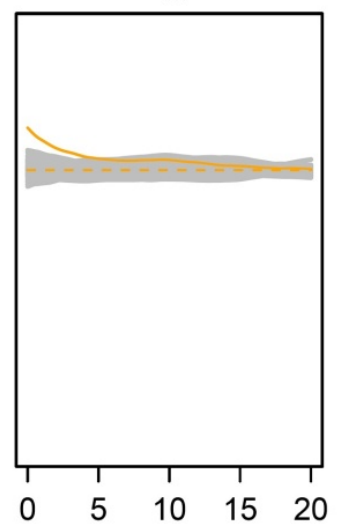

(C)

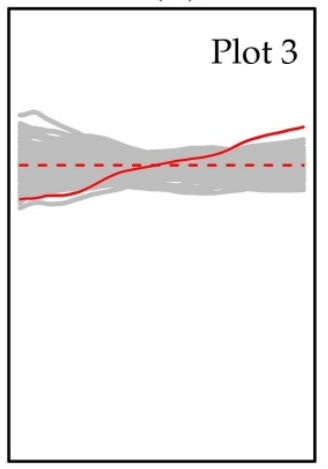

(G)

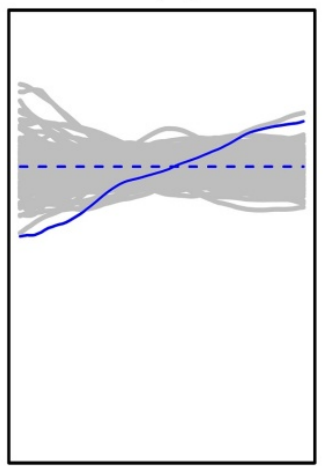

(K)

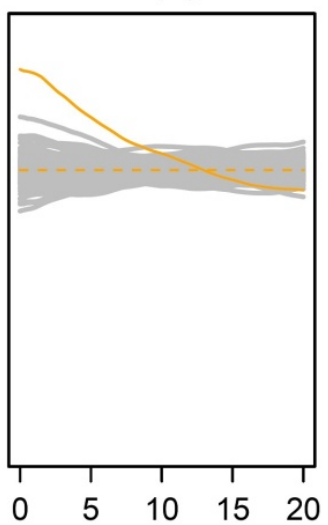

(D)

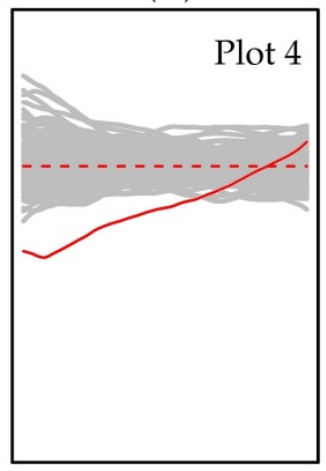

(H)

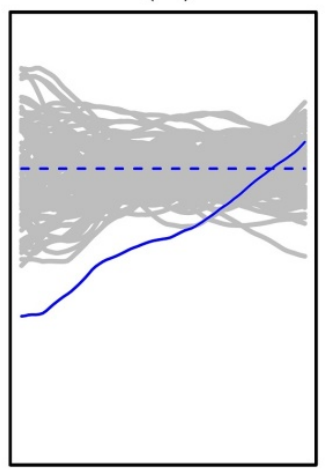

(L)

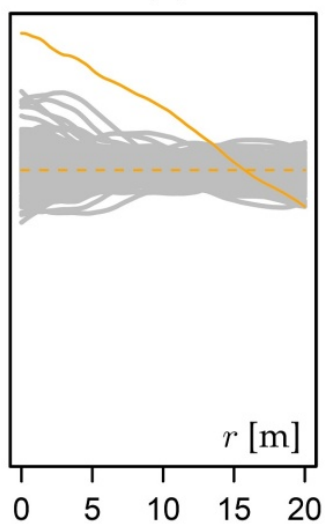

Fig. 4. Mark correlation function $\hat{k}_{m m}(r)$ using (A-D) total tree heights (red), (E-H) stem diameters (blue) and (I-L) $h / d$ ratios (orange) as marks. Grey: Pointwise envelopes from 99 random labelling simulations 
The mark variogram also suggests spatial independence for total tree heights in plot 1 (Fig. 5,A), however, it indicates a stronger positive association of marks for plot 2 (Fig. 5,B), i.e. pair of points at small $r$ with similar small heights. As with $\hat{k}_{m m}(r)$ this effect is strongest in plot 4 (Fig. 5,D). The mark variogram differentiates more clearly between the four plots than the mark correlation function. The $\hat{\gamma}(r)$ curves of height and diameter marks (Fig. 5, A-H) are largely similar, the differences between the plots are more distinctive when stem diameters are used as marks. They are all significant apart from those for plot 1 . However, the results we obtained for the $h / d$ ratio using $\hat{\gamma}(r)$ clearly differ from those we obtained from $\hat{k}_{m m}(r)$. The curves in Fig. 5 (I-L) look more similar to those in Fig. $5(\mathrm{~A}-\mathrm{H})$. The former are also not significant apart from that for plot 4 . The difference in test functions as explained in Section 2.3 is a key to understanding the different results in Fig. 4 (I-L) and Fig. 5 (I-L). Since in the mark correlation function marks are multiplied, large mark values become even higher. The mark variogram considers the differences of marks. For pairs of large marks the results returned by the test functions are very small. Positive mark association, i.e. a situation where two marks are similar, are expressed by small values in the mark variogram, i.e. $\hat{\gamma}(r)<1$, regardless whether the two marks are both small or large. The mark correlation function makes a difference between these two cases: For heights and diameters the two marks of points at small $r$ were both small. However, for the $h / d$ ratio the two marks compared for small $r$ are actually both large.
(A)

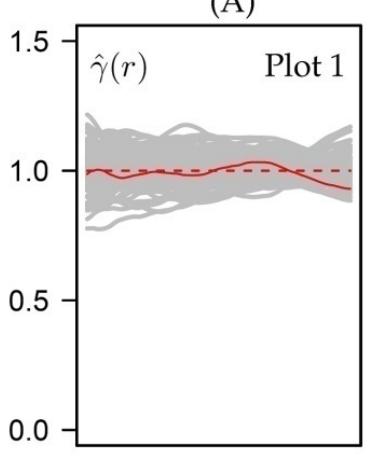

(E)

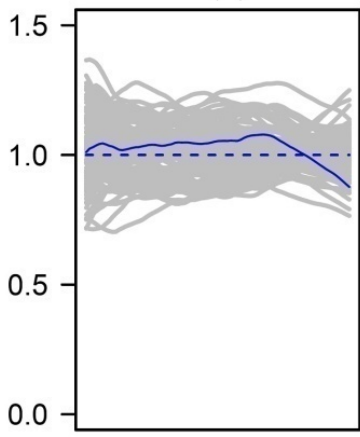

(I)

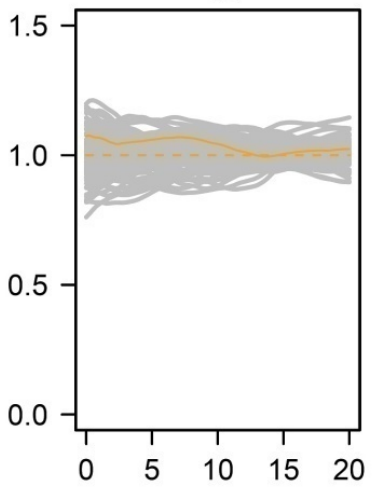

(B)

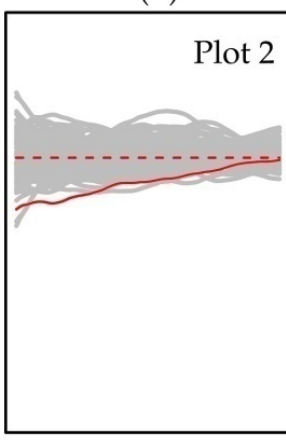

(F)

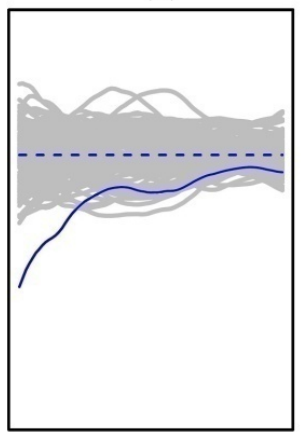

(J)

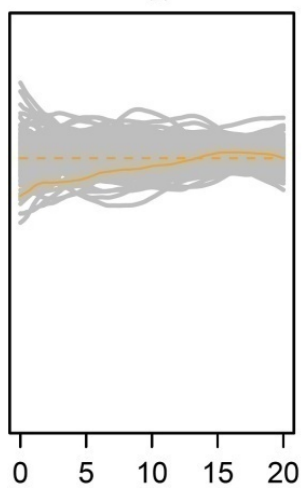

(C)

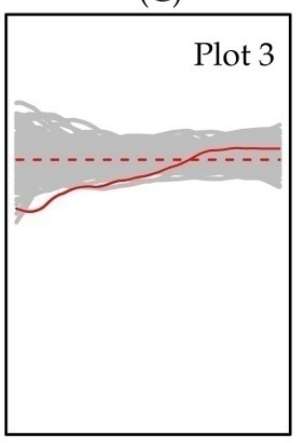

(G)

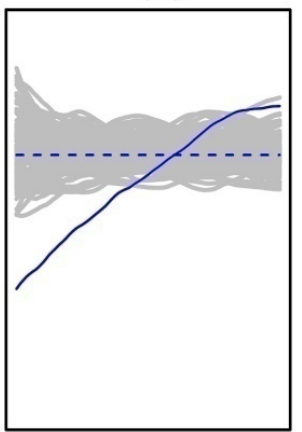

(K)

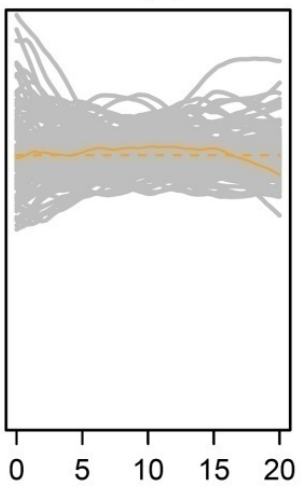

(D)

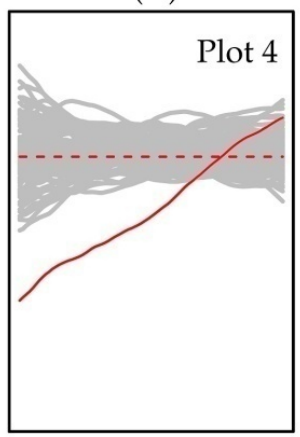

(H)

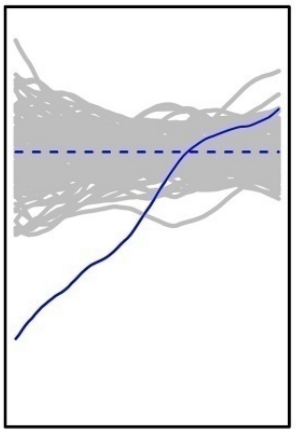

(L)

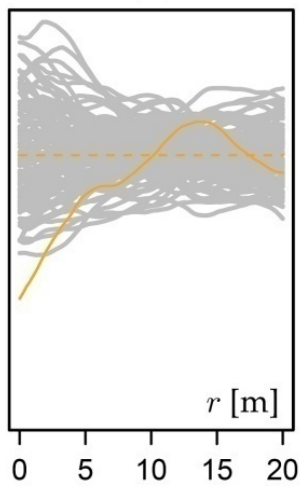

Fig. 5. Mark variogram $\hat{\gamma}(r)$ using (A-D) total tree heights (red), (E-H) stem diameters (blue) and (I-L) h/d ratios (orange) as marks. Grey: Pointwise envelopes from 99 random labelling simulations 


\section{Discussion}

Applying several alternative mark correlation functions to the same data is not very common in ecology. For example, Suzuki and others [27] used $\hat{k}_{m m}(r)$ and $\hat{\gamma}(r)$ in combination for detecting local size hierarchies in even-aged Abies forest in Japan. In their study, the authors applied total tree heights as marks.

Patterns of the mark correlation function as shown in Fig. 4 (I-L) are rare for spatial tree data. Due to competition processes it is more common to observe $k_{m m}(r)<1$ for most $r$, when total tree heights and stem diameters are considered as marks. Gonçalves and Pommerening [28] also found situations of $k_{m m}(r)>1$ in plantations of umbrella pine (Pinus pinea L.) in Portugal for large $r$, where total cone weights were used as marks.

In our study, large values of $h / d$ ratios in trees at close proximity have caused $k_{m m}(r)>1$. According to Fig. 3 these trees must be small, hence they are understorey trees. Light levels in the understorey are considerably lower than in the overstorey and therefore it is a typical strategy of small forest trees to allocate more biomass to height growth as opposed to diameter growth ("survival strategy" [7]). However, the exact allocation of biomass to height growth depends on the ability of the overstorey trees to make light less accessible to understorey trees. Here shade tolerant overstorey trees usually are more efficient than light demanding trees. Shade tolerance and light demand are fuzzy, relative notions and in the context of our study sycamore is more shade tolerant and shade casting than ash [19]. Seedlings and saplings are usually more shade tolerant than mature trees of the same species, but it certainly matters how shade casting the overstorey is. In this context, it is interesting to recall that plots 1 and 2 have an overstorey dominated by ash trees whilst sycamore trees dominate the overstorey in plots 3 and 4 . At the same time there is markedly more ash in the understorey of plots 3 and 4 (see Figs. 2 and 3). All these factors surely contributed to the findings in Fig. 4 (I-L). As part of this work we also analysed a large number of other data sets including different species, structures and a similar mix of small and mature trees. In none of these analyses we have seen such a clear trend like in Fig. 4 (I-L). Thus we conclude that our finding concerning spatial allometry in Lligwy Woods is quite special.
In total, we learned from Figs. 4 and 5 that conand heterospecific competition in Lligwy Woods have given rise to clusters of small trees interspersed by a few overstorey trees. The mark correlation function and the mark variogram for total height and diameter marks typically show this competition-size relationship that is also confirmed by Fig. 1. This view is also reinforced by Fig. 4 (I-L), however, because the mark correlation function highlights special allometric relationships at close proximity, the legacy effect of the $h / d$ ratios of new cohorts of young trees emerging into the main stand is pointed out very sharply.

In the original spatial species analysis, the results were inconclusive with regard to a possible species alternation - mainly for technical reasons. Our analysis of quantitative allometrics has helped to overcome this technical problem, since we are now able to indirectly deduct that both species have in fact adapted to one another. Even in the absence of a major disturbance ash has a good chance to continue to be a major species of this woodland community because the species has developed allometric patterns allowing ash trees to rise quickly to the main canopy.

Our study has also highlighted the need for a careful selection of test functions of the generic mark correlation function. Whilst mark variograms are usually the better choice when tree stem diameters are applied as marks, the classical mark correlation function $k_{m m}(r)$ performs well with allometric relationships and marks such as fruit weights. It certainly pays off to use alternative test functions and also to consider descriptive statistics of marks such as those in Figs. 2 and 3. Another alternative test function is for example that of the mark differentiation function [29], $t_{3}\left(m_{1}, m_{2}\right)=1-\frac{\min \left(m_{1}, m_{2}\right)}{\max \left(m_{1}, m_{2}\right)}$.

However, this test function applied to the $h / d$ marks would lead to a mark differentiation function, $\tau$, with values of $\tau(r)=0$, where $k_{m m}(r)>1$. This is not so helpful for diagnosing these particular allometric patterns that we have studied in this paper.

\section{Conclusions}

In this work, we considered spatial relations between size characteristics of trees in the uneven-aged natural forest stand. We argued that it is not sufficient to rely on single size characteristics when inferring ecological processes. Although there are strong links between sizes of parts of trees, these links are not constant and change with 
time forming allometric relationships. The allometric relations are not universal and depend on the life history of an individual tree. Using methods from spatial statistics we showed that allometric and spatial relations are tightly coupled. Our analysis suggested that spatial allometric relationships play a key role in species alternation and highlight one mechanism of how the two main species have adapted to a steady system of coexistence.

\section{Acknowledgements}

A. P. thanks his former MSc student Andrew Shinton for carrying out the field survey and for the initial analysis as part of his MSc thesis at Bangor University (Wales, UK). Z. Z. was funded by the National Natural Science Foundation of China (project No. 31670640). P. G. was supported by a grant from the Russian Foundation for Basic Research (project No. 16-04-01348).

\section{References}

1. Illian, J. Statistical analysis and modelling of spatial point patterns / J. Illian, A. Penttinen, H. Stoyan, D. Stoyan. Chichester : John Wiley \& Sons, 2008.

2. Ballani, F. $R$-scatterplots for the ecological interpretation of marked point patterns / F. Ballani, A. Pommerening, D. Stoyan // Ecography. In preparation.

3. Wiegand, T. Handbook of spatial point pattern analysis in ecology / T. Wiegand, K. A. Moloney. - Boca Raton : CRC Press, 2014.

4. Dale, M. R. T. Spatial analysis. A guide for ecologists / M. R. T. Dale, M.-J. Fortin. $-2^{\text {nd }}$ edition. - Cambridge : Cambridge University Press, 2014.

5. O'Sullivan, D. Spatial simulation. Exploring pattern and process / D. O'Sullivan, G. L. W. Perry. - Chichester : Wiley-Blackwell, 2013.

6. Shinton, A. Spatial analysis and a possible alternation of ash (Fraxinus excelsior L.) and sycamore (Acer pseudoplatanus L.) in Lligwy Woods / A. Shinton. - MSc thesis, Bangor : Bangor University, 2008.

7. Pretzsch, H. Forest dynamics, growth and yield. From measurement to model / H. Pretzsch. - Heidelberg : Springer, 2009.

8. Waters, T. L. Ash and sycamore regeneration and the phenomenon of their alternation / T. L. Waters, P. S. Savill // Forestry. - 1992. - Vol. 65. - P. 417-433.

9. Peterken, G. F. Natural woodland, ecology and conservation in northern temperate regions / G. F. Peterken. Cambridge : Cambridge University Press, 1996.

10. Scurfield, G. Ash woods of Derbyshire carboniferous limestone: Monk's Dale / G. Scurfield // The Journal of Ecology. - 1959. - Vol. 47. - P. 357-369.

11. Peterken, G. F. Woodland conservation and management / G. F. Peterken. $-2^{\text {nd }}$ edition. - London : Chapman and Hall, 1981.

12. Niklas, K. J. Plant allometry / K. J. Niklas. - Chicago : The University of Chicago Press, 1994.

13. Huxley, J. S. Problems of relative growth / J. S. Huxley. - New York : Lincoln Mac Veagh Dial ; The Dial Press, 1932.

14. Niklas, K. J. Plant physics / K. J. Niklas, H.-C. Spatz. - Chicago : The University of Chicago Press, 2012.

15. Causton, D. R. The biometry of plant growth / D. R. Causton, J. C. Venus. - London : Edward Arnold, 1981.

16. Hunt, R. Basic growth analysis: Plant growth analysis for beginners / R. Hunt. - London : Unwin Hyman, 1990.

17. Pommerening, A. Relative plant growth revisited: Towards a mathematical standardisation of separate approaches / A. Pommerening, A. Muszta // Ecological Modelling. - 2016. - Vol. 320. - P. 383-392.

18. Mitchell, S. J. Stem growth responses in Douglas fir and Sitka spruce following thinning: implications for assessing windfirmness / S. J. Mitchell // Forest Ecology and Management. - 2000. - Vol. 135. - P. 105-114.

19. Kramer, H. Waldwachstumslehre. [Forest growth and yield science.] / H. Kramer. - Hamburg and Berlin : Verlag Paul Parey, 1988.

20. Baddeley, A. Spatial point patterns. Methodology and applications with R / A. Baddeley, E. Rubak, R. Turner. Boca Raton : CRC Press, 2016.

21. Ohser, J. On the second-order and orientation analysis of planar stationary point processes / J. Ohser, D. Stoyan // Biometrical Journal. - 1981. - Vol. 23. - P. 523-533.

22. On tests of spatial pattern based on simulation envelopes / A. Baddeley, P. J. Diggle, A. Hardegen, T. Lawrence, R. K. Milne, G. Nair // Ecological Monographs. - 2014. - Vol. 84. - P. 477-489.

23. Grabarnik, P. Correct testing of mark independence for marked point patterns / P. Grabarnik, M. Myllymäki, D. Stoyan // Ecological Modelling. - 2011. - Vol. 222. - P. 3888-3894.

24. Global envelope tests for spatial processes / M. Myllymäki, T. Mrkvička, P. Grabarnik, H. Seijo, U. Hahn // Journal of the Royal Statistical Society : Series B (Statistical Methodology). - 2017. - Vol. 79. - P. 381-404.

25. R: A language and environment for statistical computing / R Development Core Team. - Viena : R Foundation for Statistical Computing. - 2018. - URL: http://www.r-project.org

26. Peterson, H. Die Massenproduktion des Nadelwaldes. [Volume production of conifer forests.] / H. Petterson // Mitteilungen der Schwedischen Forstlichen Forschungsanstalten 45. - Stockholm, 1955. 
27. Suzuki, S. N. Development of local size hierarchy causes regular spacing of trees in an aven-aged Abies forest: Analyses using spatial autocorrelation and the mark correlation function / S. N. Suzuki, N. Kachi, J.-I. Suzuki // Annals of Botany. - 2008. - Vol. 102. - P. 435-441.

28. Gonçalves, A. C. Spatial dynamics of cone production in Mediterranean climates: A case study of Pinus pinea L. in Portugal / A. C. Gonçalves, A. Pommerening // Forest Ecology and Management. - 2011. - Vol. 266. - P. 83-93.

29. Hui, G. Analysing tree species and size diversity patterns in multi-species uneven-aged forests of Northern China / G. Hui, A. Pommerening // Forest Ecology and Management. - 2014. - Vol. 316. - P. 125-138.

\section{References}

1. Illian J., Penttinen A., Stoyan H., Stoyan D. Statistical analysis and modelling of spatial point patterns. Chichester: John Wiley \& Sons, 2008.

2. Ballani F., Pommerening A., Stoyan D. Ecography. In preparation.

3. Wiegand T., Moloney K. A. Handbook of spatial point pattern analysis in ecology. Boca Raton: CRC Press, 2014.

4. Dale M. R. T., Fortin M.-J. Spatial analysis. A guide for ecologists. 2nd edition. Cambridge: Cambridge University Press, 2014.

5. O'Sullivan D., Perry G. L. W. Spatial simulation. Exploring pattern and process. Chichester: Wiley-Blackwell, 2013.

6. Shinton A. Spatial analysis and a possible alternation of ash (Fraxinus excelsior L.) and sycamore (Acer pseudoplatanus L.) in Lligwy Woods. MSc thesis, Bangor: Bangor University, 2008.

7. Pretzsch H. Forest dynamics, growth and yield. From measurement to model. Heidelberg: Springer, 2009.

8. Waters T. L., Savill P. S. Forestry. 1992, vol. 65, pp. 417-433.

9. Peterken G. F. Natural woodland, ecology and conservation in northern temperate regions. Cambridge: Cambridge University Press, 1996.

10. Scurfield G. The Journal of Ecology. 1959, vol. 47, pp. 357-369.

11. Peterken G. F. Woodland conservation and management. 2nd edition. London: Chapman and Hall, 1981.

12. Niklas K. J. Plant allometry. Chicago: The University of Chicago Press, 1994.

13. Huxley J. S. Problems of relative growth. New York: Lincoln Mac Veagh Dial; The Dial Press, 1932.

14. Niklas K. J., Spatz H.-C. Plant physics. Chicago: The University of Chicago Press, 2012.

15. Causton D. R., Venus J. C. The biometry of plant growth. London: Edward Arnold, 1981.

16. Hunt R. Basic growth analysis: Plant growth analysis for beginners. London: Unwin Hyman, 1990.

17. Pommerening A., Muszta A. Ecological Modelling. 2016, vol. 320, pp. 383-392.

18. Mitchell S. J. Forest Ecology and Management. 2000, vol. 135, pp. 105-114.

19. Kramer H. Waldwachstumslehre. [Forest growth and yield science]. Hamburg and Berlin: Verlag Paul Parey, 1988.

20. Baddeley A., Rubak E., Turner R. Spatial point patterns. Methodology and applications with R. Boca Raton: CRC Press, 2016.

21. Ohser J., Stoyan D. Biometrical Journal. 1981, vol. 23, pp. 523-533.

22. Baddeley A., Diggle P. J., Hardegen A., Lawrence T., Milne R. K., Nair G. Ecological Monographs. 2014, vol. 84, pp. 477-489.

23. Grabarnik P., Myllymäki M., Stoyan D. Ecological Modelling. 2011, vol. 222, pp. 3888-3894.

24. Myllymäki M., Mrkvička T., Grabarnik P., Seijo H., Hahn U. Journal of the Royal Statistical Society: Series B (Statistical Methodology). 2017, vol. 79, pp. 381-404.

25. Available at: http://www.r-project.org

26. Peterson H. Die Massenproduktion des Nadelwaldes. [Volume production of conifer forests]. Mitteilungen der Schwedischen Forstlichen Forschungsanstalten 45. Stockholm, 1955.

27. Suzuki S. N., Kachi N., Suzuki J.-I. Annals of Botany. 2008, vol. 102, pp. 435-441.

28. Gonçalves A. C., Pommerening A. Forest Ecology and Management. 2011, vol. 266, pp. 83-93.

29. Hui G., Pommerening A. Forest Ecology and Management. 2014, vol. 316, pp. 125-138. 